\title{
Effects of Mobile Phone and Base Station Radiations on Living Being
}

\author{
Ragini Saxena* and D.M. Kumawat \\ School of Studies in Environment Management, Vikram University, Ujjain, \\ $M P-456010$, India \\ *Corresponding author
}

\section{Keywords}

Distance, Radio

frequency, Ill-Health,

Radiation, Teenager,

Middle aged

Article Info

Accepted:

06 May 2018

Available Online:

10 June 2018

\section{A B S T R A C T}

Due to increase in telecommunication facilities, Ujjain, simple and holy city is crowded by number of Mobile Base Stations. Also mobile phone users are also increasing day by day due to its excessive use and dependence. The aim of the present study is to investigate the association of use of mobile phones and radio frequency exposure to base stations with fatigue, headache, dizziness, tension and sleep disturbance etc. in adolescents and adults population of Ujjain and to provide an outcome which can deal with health and social awareness. A survey was conducted among 100 teenager students of age 14-19 years and 100 middle aged people aged 30-45 years of few schools and offices of Ujjain, India. A questionnaire was developed and the primary data in the form of Yes / No was collected and studied. The study showed increased association of fatigue, sleep disturbance, dizziness, loss of mental attention, memory loss, headache, earache, tachycardia, poor eye sight and anxiety while diarrhea and constipation were associated with less frequency as per the interview of the subjects. Also environmental effects were associated in the form of bacterial burden and effect on plant population responsible for ecological imbalance. People living or stay over a long time near mobile based station to ascertain level radiation and make effort to screen the radiation if perceived danger, also individual should reduce their level of making or receiving call with their mobile to avoid some of the potential hazard mentioned conversation with text messages could be a better option. In general, it's our duty to keep the mobile phones as far as possible from our body during our daily life.

\section{Introduction}

Worldwide, mobile phone and base station radiation have effect on the health of human being, is a matter of interest and research due to enormous usage of mobile phones throughout the world therefore it makes a global burden on the population. Electromagnetic radiations are used in mobile phones, found in the microwave range i.e. 450-2100 MHz, also other digital wireless systems, for example data communication networks, produce similar type of radiation. Mobile phone use becomes a status symbol as well as a necessity because it serve as a mean of an indispensible communication commonly used by most of the people, due to countless perks provided by the phones.

Worldwide mobile phone subscription has reached from 12.4 millions connections to over 5.6 billions, involving $70 \%$ of the global population in the last 20 years (World Health Organization, 2011). 
The mobile phones transmit and receive microwave radiations at frequencies of about $900 \mathrm{MHz}$ and $1,800 \mathrm{MHz}$ respectively and these frequencies excite rotation of water molecules and some organic molecules. (Szentpali, 1999) There are two main and direct ways of exposure to radio frequency radiations such as thermal effects caused by holding mobile phones close to the body and possible non-thermal effects, can affect health. Teenagers have more detrimental effect due to cell phone radiation as they absorb more energy due to their smaller size of head and brain, cranial bones and skin are thin, elasticity and more younger cells in the ear, low blood volume of blood and more younger cells in blood and more fast conduction of nerve leads to more penetration of energy than adults from the same device. Adverse health conditions caused by electromagnetic field (EMF) radiations are headache, sleep disorders, lack of concentration, impairment of memory, dizziness, high blood pressure, increased frequency of seizures in epileptic children, and brain tumor etc. (Michael et al., 2000)

\section{Materials and Methods}

\section{Sources of Data collection}

Data collected from teenagers aged 14-19 and middle aged population of age 30-45 years of Ujjain, study was conducted at selected schools and houses / work places situated within 350 meter radius from base stations in Ujjain.

\section{Population}

Teenager students of selected schools using mobile phones and / or living within the radius of 350 meter from base stations and young adults living within a radius of 350 meter from base stations and / or using mobile phones in Ujjain was the population for study.

\section{Sample}

Teenager Students attended selected schools and / or lived nearer to base stations and middle aged people lived nearer to base stations and / or using mobile phones was the samples for study. A survey was conducted among 100 teenager students of age 14-19 years and 100 middle aged people aged 30-45 years of few schools and offices in Ujjain, India. Simple randomized sampling was used to select Teenagers and middle aged people in Ujjain.

\section{Inclusion criteria}

Available at the time of data collection. Willing to participate in the study. Can read, write and speak English.

\section{Exclusion criteria}

Cognitive or hearing problems

A descriptive survey design was used to extract answers to the questionnaires administrated to middle aged people and teenager students who were studied in selected schools with prior approval of the Principle and their teachers in Ujjain city, Madhya Pradesh, a state in India.

Characteristic profile (Age, educational status, area and family income) and health risks associated with mobile phone usage and living near vicinities of mobile base stations was the two main criteria on which study of mobile phone usage among the teenagers and middle aged people was conducted. A total of 100 teenagers and 100 middle aged people were selected for the survey.

General questions pertained to estimated distance from base stations (less than $10 \mathrm{~m}, 10$ to $50 \mathrm{~m}, 50$ to $100 \mathrm{~m}, 100$ to $200 \mathrm{~m}, 200$ to $300 \mathrm{~m}$, more than $300 \mathrm{~m}$ ) and their location in 
relation to the antennas (facing, beside, behind, beneath in the case of antennas placed on rooftops).

Perception questionnaire on mobile phone and base station radiation hazard studies

Name:

Students ID (for Students):

Genders: Male / Female

Ages:

Date of birth:

Courses (for Students):

Do you use a cell phone: Yes / No

How long have you been using a cell phone (MM/YY):

How many cell phones you use currently:

Cell phone(s) brand that you're using:

Where do you carry your cell phone: pouch / pocket / around your neck / in the bag / any other

Are you living near to a Mobile Base Station: Yes / No

If yes, how far is it from your home/school/work place?

$<10$ meters

10-50 meters

50-100 meters

100-200 meters

200-300meters

$>350$ meters

Average no. of calls received/dialed daily:
The average duration you talk (both incoming and outgoing) on the phone daily (in minutes):

Which ear that you normally use when you're on the phone: right / left / both / not sure

Average no. of SMS received/sent daily:

Are you using any cell phone accessory(s): Bluetooth: yes / no Hands free: yes / no

Do you use cell phone while driving: Yes / No

Each call in minutes received/called for 3 consecutive days:

Do you think the following health hazards are associated to cell phone usage?

Are you aware of the several unwanted effects of using the cell phone: Yes / No

How do you think you can minimize the unwanted effects?

Decrease the talking duration: Yes / No Increase the length of hands free: Yes / No

Any other method(s):

Do you actually practice any of these measures: Yes / No

If no, why?

\section{Results and Discussion}

There are several studies that is related with the damage to the body such as memory confusion and memory lapses, headaches and whizzing sounds in the ear, cause headaches and induce extreme fatigue, create joint pain, muscle spasms and tremors, create burning sensation and rash on the skin, alter the brain's electrical activity during sleep, induce ringing in the ears etc. (Khan et al., 2008). A study conducted by Santini et al., (2003) in France 
on a variety of self-reported symptoms for people who reported that they were living at a distance of less than 300 meters in rural area while in urban area within 100 meters from mobile base stations having the symptoms of fatigue, sleep disturbance, headache and loss of memory etc. Fatigue, irritability, headache, nausea, appetite loss, discomfort, gait difficulty was reported by Enrique et al., (2003), headaches, exhaustion tiredness, difficulties to concentrate, feeling strained, urge for sleep were observed by Hutter et al., (2006), Higher concentrations of alphaamylase in their saliva, obsessive-compulsive, anxiety was observed by Viel et al., (2009), while headache, skin irritation, anxiety, sleep disorder, weight loss was seen by Akintonwa et al., (2009) which were correlated with our study as it showed the similar level of discomfort in our target population.

This is a real environmental concern in many developing countries, since the nondiscriminatory manner in which these base stations are sited in close proximity to residential homes, offices, hospitals and schools increases the exposure level in such environment as shown in the study done by Otitoloju et al., (2010), indicates that the mobile base station should not be in close proximity to residential area. These surveys are not of so much importance as they are not having statistically significant data which include most of the representative part of the population and those people which are less in number, having complaint of severe adverse effect are to be cautious and must take appropriate precaution regarding radiation. Conducting studies on populations living near to base stations, for the assessment of radiation exposure individually would be a big task.

An additional reason is the use of mobile phones during the school hours, as in the result outcome of a study, $36.1 \%$ students use the mobile phone in the School premises and
$51 \%$ said that their teacher are familiar with their mobile usage in the schools. In the United States, the majority of public schools have a rule against the use of cell phones in school, which requires students to either leave their phones at home or keep them in the switched off mode during the school hours in a study done by Obringer and Coffey (2007). Other schools have started a policy where students are allowed to use cell phones either before or after the school hours only and not within school hours in a study shown by Gerard (2006). Conversely, parents feel that if the child have mobile phone it improve their safety and protection as their location can be assessed and can remain in constant touch with their child and maintain a record of their children school activities or even contact them if any emergency arises as said by Obringer and Coffey in 2007 and Zirkel shown in a study done in 2008 (Gerard, 2006; Zirkel, 2008). In our survey, we found that students were not exactly aware about the ecosystem disturbance by the use of mobile phones which is quite critical. Our system suffers the ill effects of mobile phone radiations as well. The most recent example is the noticeable increased use of these in the population.

Tinnitus, also k/a "Ringxiety"- a psychological disease of having sensation and hearing of cell phone ring in millions of cell phone users in the world, is mainly found in the people who are addict of mobile phones or in new users. These people have severe trouble in hearing, while they are working in a serious task or even when they are sleeping.

Radiation induced irreversible damage to the delicate working of inner ear can occur due to long term and addicted use of mobile phones for a duration of four years or more and in a day of approximately 30 minutes or more carries a higher risk of developing deafness either mild, moderate or severe (Fig. 1 and 2; Table 1-5). 
Table.1 Showing the result of interview questionnaire as per the knowledge of the subjects

\begin{tabular}{|c|c|c|c|}
\hline Tasks & Criteria & Age $14-19$ years $\%$ & Age $30-45$ years $\%$ \\
\hline \multirow[t]{2}{*}{ Are you living near a mobile base station } & Yes & 28 & 41 \\
\hline & No & 72 & 59 \\
\hline \multirow{4}{*}{$\begin{array}{l}\text { If yes, how far is it from your } \\
\text { home/school/workplace (In Metres) }\end{array}$} & $<100$ & 14 & 31 \\
\hline & $>300$ & 31 & 30 \\
\hline & $100-200$ & 25 & 23 \\
\hline & $200-300$ & 30 & 16 \\
\hline \multirow{5}{*}{$\begin{array}{l}\text { How much time do you spent near base station } \\
\text { vicinity (In Hrs) }\end{array}$} & $<3$ & 62 & 36 \\
\hline & $3-8$ & 13 & 28 \\
\hline & $8-12$ & 10 & 12 \\
\hline & $12-18$ & 13 & 21 \\
\hline & $18-24$ & 2 & 3 \\
\hline \multirow[t]{2}{*}{ Average number of calls received/dialed daily } & $<10$ & 81 & 65 \\
\hline & $>10$ & 19 & 35 \\
\hline \multirow[t]{2}{*}{ Average time duration of daily talk (In Hrs) } & $<1$ & 99 & 96 \\
\hline & $>1$ & 1 & 4 \\
\hline \multicolumn{4}{|c|}{ Do you think the following health hazards are associated to cell phone usage } \\
\hline \multirow[t]{2}{*}{ Fatigue } & Agree & 66 & 71 \\
\hline & Disagree & 34 & 29 \\
\hline \multirow[t]{2}{*}{ Sleep Disturbance } & Agree & 87 & 78 \\
\hline & Disagree & 13 & 22 \\
\hline \multirow[t]{2}{*}{ Dizziness } & Agree & 64 & 66 \\
\hline & Disagree & 36 & 34 \\
\hline \multirow[t]{2}{*}{ Loss of Mental attention } & Agree & 83 & 81 \\
\hline & Disagree & 17 & 19 \\
\hline \multirow[t]{2}{*}{ Memory Loss } & Agree & 51 & 74 \\
\hline & Disagree & 49 & 26 \\
\hline \multirow[t]{2}{*}{ Headache } & Agree & 80 & 74 \\
\hline & Disagree & 20 & 26 \\
\hline \multirow[t]{2}{*}{ Earache } & Agree & 70 & 72 \\
\hline & Disagree & 30 & 28 \\
\hline \multirow[t]{2}{*}{ Tachycardia } & Agree & 54 & 53 \\
\hline & Disagree & 46 & 47 \\
\hline \multirow[t]{2}{*}{ Diarrhea } & Agree & 16 & 28 \\
\hline & Disagree & 84 & 72 \\
\hline \multirow[t]{2}{*}{ Constipation } & Agree & 24 & 34 \\
\hline & Disagree & 76 & 66 \\
\hline \multirow[t]{2}{*}{ Poor Eye Sight } & Agree & 75 & 63 \\
\hline & Disagree & 25 & 37 \\
\hline \multirow[t]{2}{*}{ Anxiety } & Agree & 75 & 70 \\
\hline & Disagree & 25 & 30 \\
\hline
\end{tabular}


Table.2 Effect of base station radiations on the number of bacterial and fungal spores

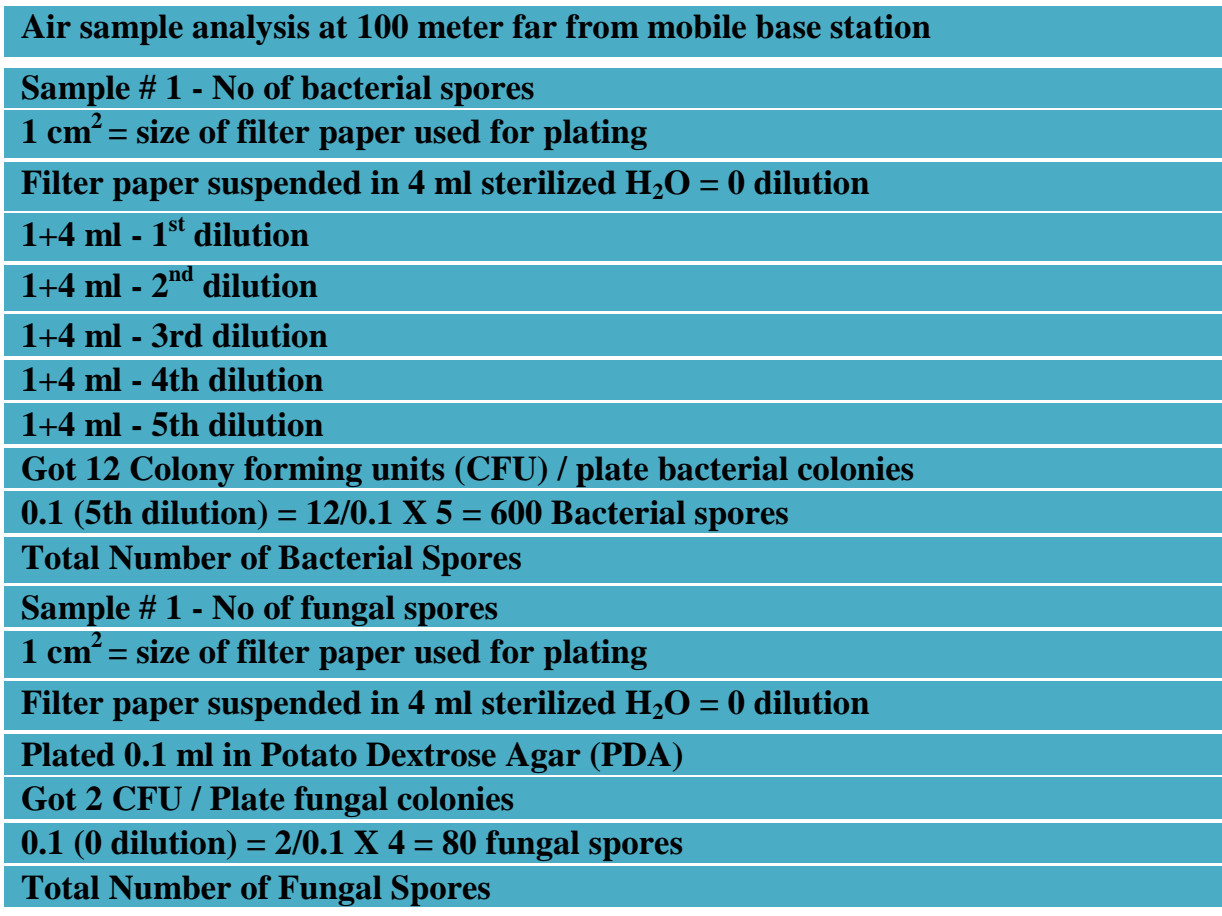

Table.3 Air sample analysis at more than $\mathbf{5 0 0}$ meter far from mobile base station
Filter paper suspended in $4 \mathrm{ml}$ sterilized $\mathrm{H}_{2} \mathrm{O}=0$ dilution

\section{$1+4 \mathrm{ml}-1^{\text {st }}$ dilution}

\section{Plated $0.2 \mathrm{ml}$ in nutrient agar}

Got 234 Colony forming units (CFU) / plate bacterial colonies

\section{$0.2(1$ st dilution $)=234 / 0.2$ X 5 = 5850 Bacterial spores}

\section{Total Number of Bacterial Spores}

Sample \# 2 - No of fungal spores

$1 \mathrm{~cm}^{2}=$ size of filter paper used for plating

Filter paper suspended in $4 \mathrm{ml}$ steralized $\mathrm{H}_{2} \mathrm{O}=0$ dilution

Plated $0.2 \mathrm{ml}$ in Potato Dextrose Agar (PDA)

Got 9 CFU / Plate fungal colonies

$0.2(0$ dilution $)=9 / 0.2 \times 4=180$ fungal spores

Total Number of Fungal Spores

\begin{tabular}{l}
$375000 \times 4=1500000$ \\
$75000 \times 5=375000$ \\
$15000 \times 5=75000$ \\
$3000 \times 5=15000$ \\
$600 \times 5=3000$ \\
\hline 600 \\
\hline $15 \times 10^{5}$ \\
\hline \\
\hline \\
\hline
\end{tabular}

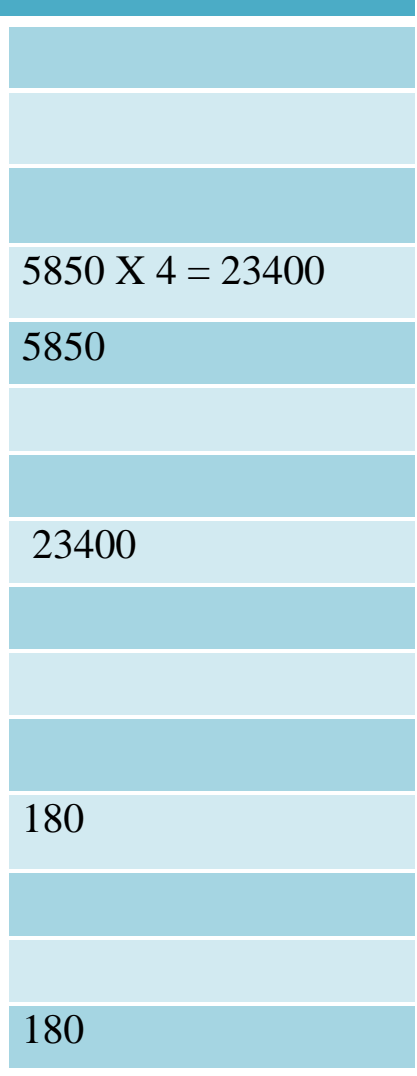


Table.4 Audiometry of few of the samples shows that continuous and more use of mobile cause impairment in hearing

\begin{tabular}{|c|c|c|c|c|c|}
\hline \multirow{2}{*}{$\begin{array}{l}\text { S. } \\
\text { No. }\end{array}$} & \multicolumn{2}{|c|}{ Left ear } & \multicolumn{2}{|c|}{ Right ear } & \multirow[t]{2}{*}{ Inference } \\
\hline & $\begin{array}{l}\text { Frequency } \\
\text { (in KHz) }\end{array}$ & $\begin{array}{l}\text { Sound (in } \\
\text { dB) }\end{array}$ & $\begin{array}{l}\text { Frequency (in } \\
\text { KHz) }\end{array}$ & Sound (in dB) & \\
\hline 1. & 6000 & 25 & 6000 & 25 & Bilateral normal hearing \\
\hline 2. & 6000 & 55 & 6000 & 60 & Bilateral moderate sensori-neural hearing loss \\
\hline 3. & 8000 & 40 & 6500 & 65 & $\begin{array}{l}\text { Bilateral moderate sensori-neural hearing loss in left ear } \\
\& \text { moderate mixed hearing loss in right ear }\end{array}$ \\
\hline 4. & 6000 & 15 & 6000 & 15 & Bilateral normal hearing \\
\hline 5. & 6000 & 40 & 6000 & 40 & Bilateral mild conductive hearing loss \\
\hline 6. & 6000 & 20 & 6000 & 25 & Bilateral mild conductive hearing loss \\
\hline 7. & 6000 & 20 & 6000 & 25 & Bilateral normal hearing \\
\hline 8. & 6000 & 10 & 6000 & 15 & Bilateral normal hearing \\
\hline 9. & 6000 & 15 & 6000 & 20 & Bilateral normal hearing \\
\hline 10. & 6000 & 10 & 6000 & 20 & Bilateral normal hearing \\
\hline 11. & 6000 & 10 & 6000 & 20 & Bilateral normal hearing \\
\hline
\end{tabular}

Table.5 Effect of Wi-Fi (Router) Radiations on the growth of seeds of different crops

\section{Effect of Wi-Fi(Router) Radiations on the growth of seeds of different crops}

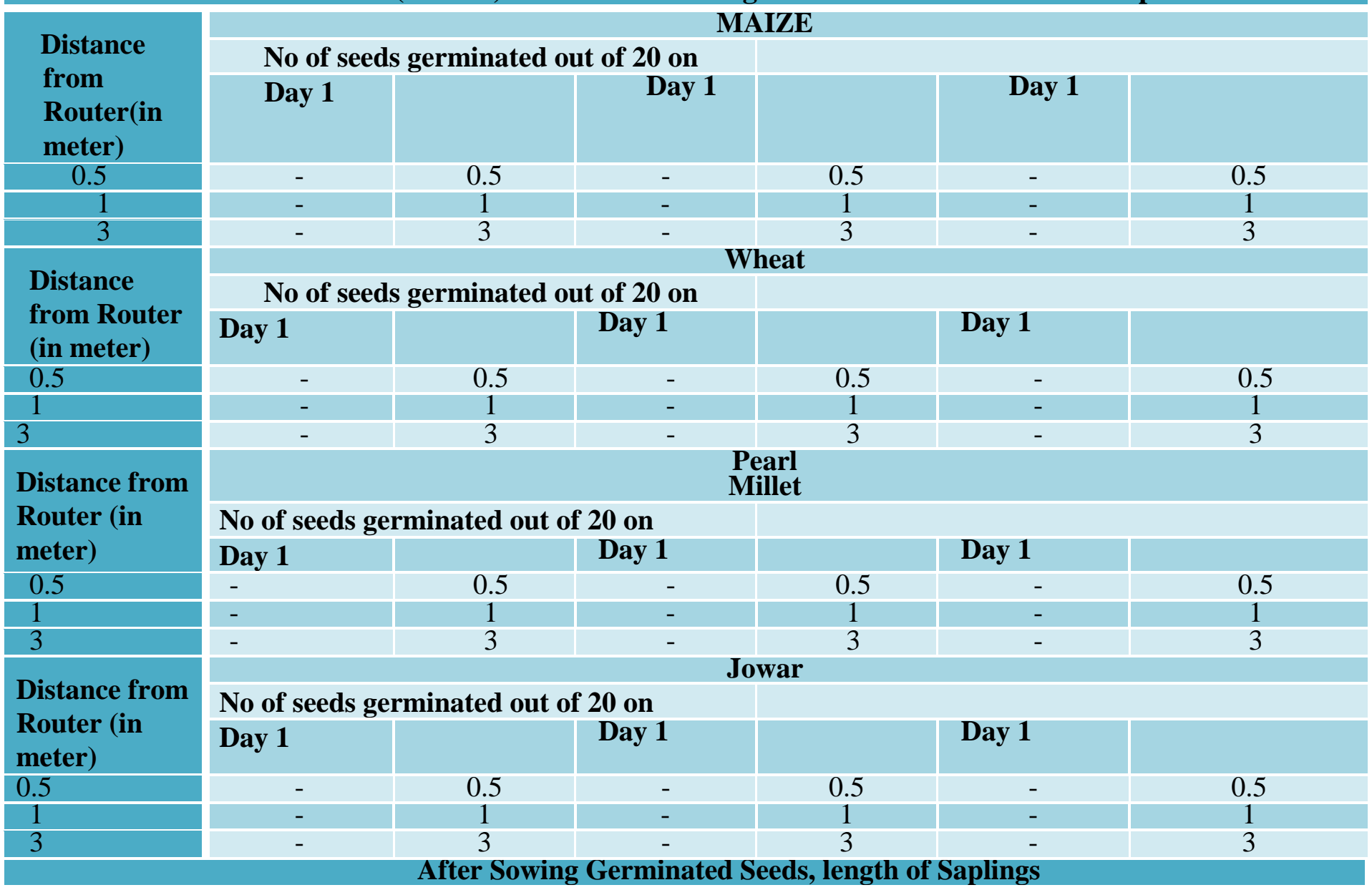




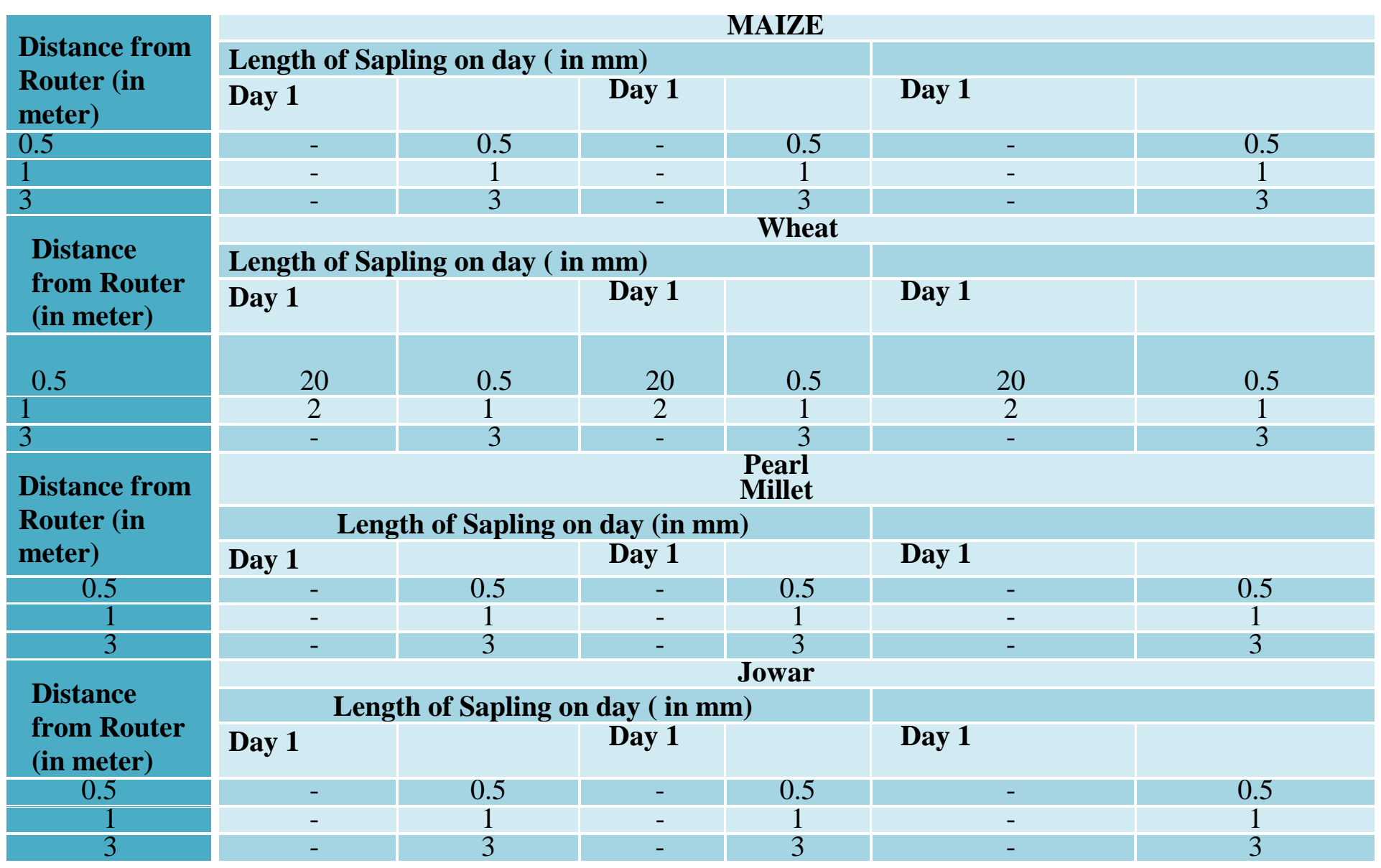

Do you think the following health hazards are associated to cell phone usage?

\begin{tabular}{|c|c|c|c|c|c|}
\hline Health hazards & $\begin{array}{l}\text { Strongly } \\
\text { disagree }\end{array}$ & Disagree & $\begin{array}{l}\text { Slightly } \\
\text { agree }\end{array}$ & Agree & $\begin{array}{l}\text { Strongly } \\
\text { agree }\end{array}$ \\
\hline \multicolumn{6}{|l|}{ Fatigue } \\
\hline \multicolumn{6}{|c|}{ Sleep Disturbance } \\
\hline \multicolumn{6}{|l|}{ Dizziness } \\
\hline \multicolumn{6}{|c|}{ Loss of Mental Attention } \\
\hline \multicolumn{6}{|c|}{ Memory Loss } \\
\hline \multicolumn{6}{|l|}{ Headache } \\
\hline \multicolumn{6}{|c|}{ Tachycardia (increased heart rate) } \\
\hline \multicolumn{6}{|l|}{ Diarrhea } \\
\hline \multicolumn{6}{|l|}{ Constipation } \\
\hline \multicolumn{6}{|l|}{ Poor Eye Sight } \\
\hline Anxiety & & & & & \\
\hline
\end{tabular}


Fig.1 Showing the results of agreement / disagreement regarding fatigue, sleep disturbance, dizziness, loss of mental attention, memory loss and headache

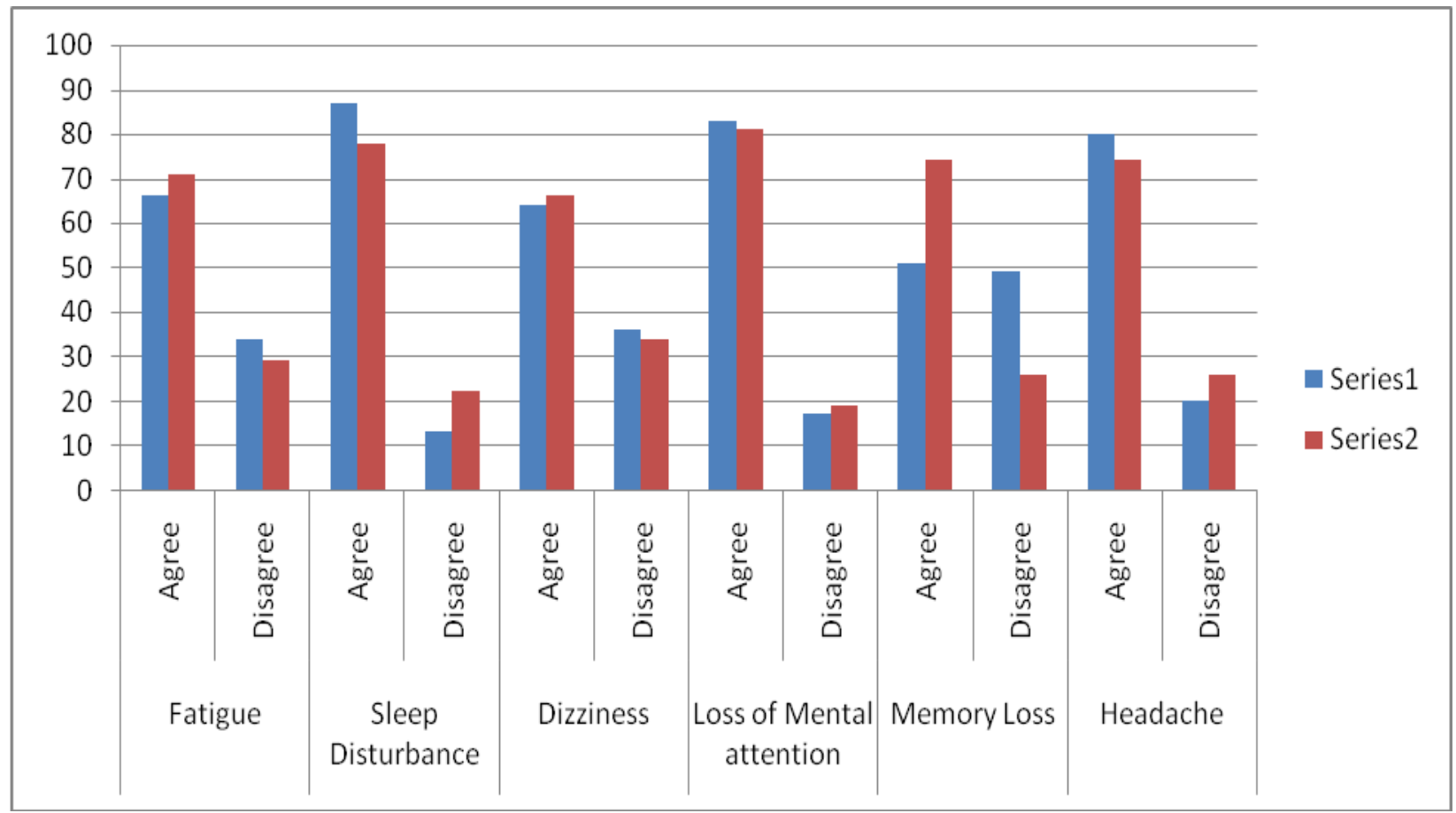

Fig.2 Showing the results of agreement / disagreement regarding earache, tachycardia, diarrhea, constipation, poor eye sight and anxiety

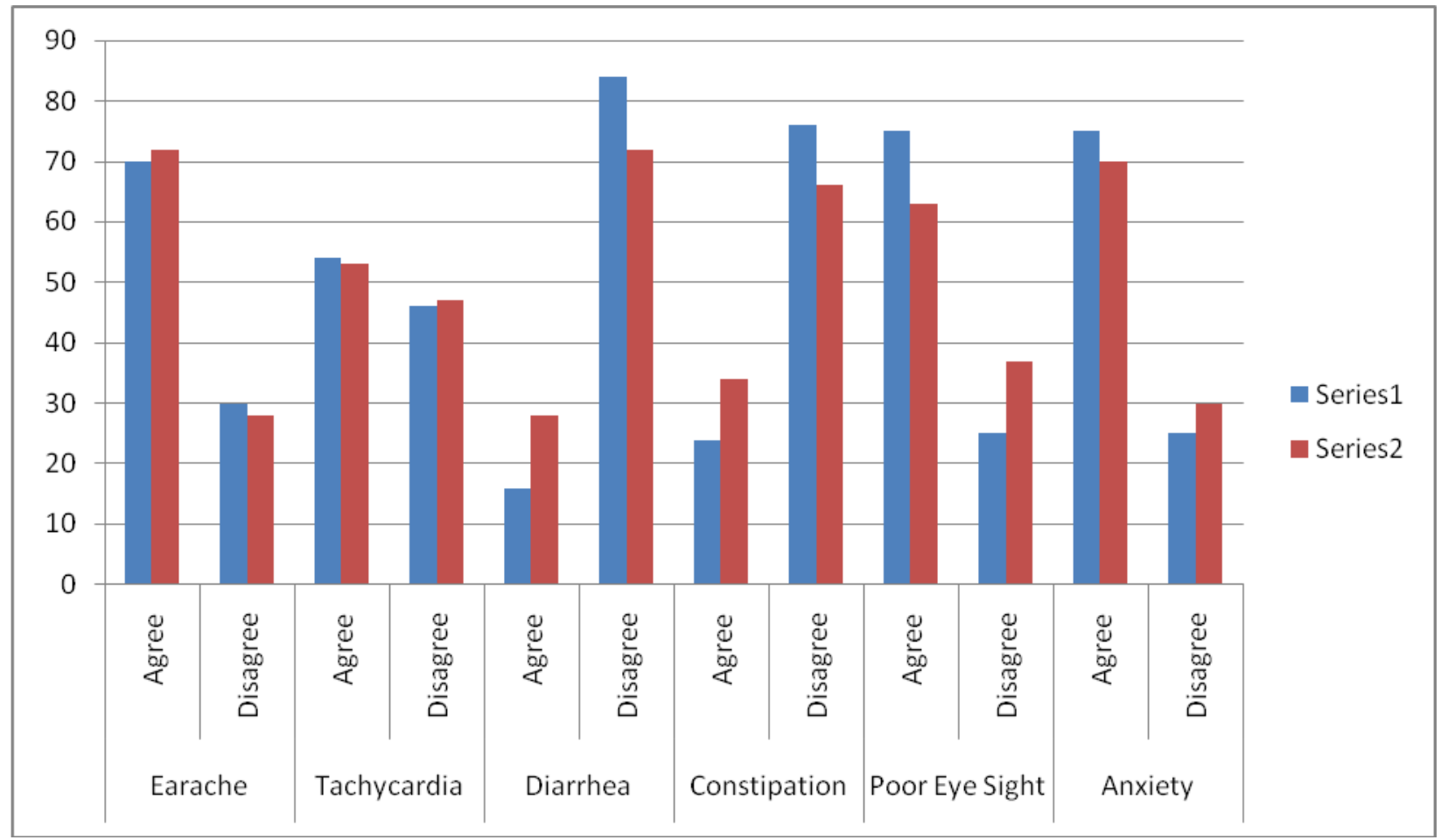


When a person head is illuminated with microwave, auditory perception can occurs as it launches a thermo-elastic wave of acoustic pressure travels through bone conduction in the inner ear, activates cochlear receptors like as the process of normal hearing, explains the "clicks" of microwave radiation, heard by people. Normal hearing depends on healthy 16,000 hair cells in inner ear as their damage leads to permanent hearing loss as these cells can't regenerate in spite that many doctors treat these patients. Now a day young aged persons of age between 18-25 years suffer from hearing loss which can be due to excessive use of mobile phones, high pitch of speaker's etc. Marketing and telecommunication people are having these problems as there works depends on the excessive use of mobile phones, in these persons the affection to inner ear starts with pain in the ear, with time associated with tinnitus or a ringing sensation which finally leads to permanent hearing loss, as minimum duration they spent may be two to three hours or more leads to permanent deafness in three to five years.

In our study environmental effects were associated in the form of bacterial and fungal burden and effect on plant population which is responsible for ecological imbalance as radiation have effect on cellular mitotic as well as meiotic function, having effect on the structure of DNA and its alteration responsible for development of cancers, can affect the food growth as it effect the growth of plant therefore less use of mobile phone lead to less radiation effect, also less number of mobile base stations leads to less exposure to the population and less development of complication.

Proximity with the mobile base stations may result to adverse health effects such as fatigue, sleep disturbances, headaches, feeling of discomfort, and difficulty in concentrating, depression, memory loss, visual disruptions, irritability, hearing disruptions, skin problems, cardiovascular disorders, and dizziness. The level of the symptom depends on: Length of period individuals have stayed or live near the base station; Length of time individual spent on receiving or making calls with his/her mobile phone.

Consequently we recommended that people living or stay over a long time near mobile based station to ascertain level radiation and make effort to screen the radiation if perceived danger, also individual should reduce their level of making or receiving call with their mobile to avoid some of the potential hazard mentioned conversation with text messages could be a better option. In general, it's our duty to keep the mobile phones as far as possible from our body during our daily life.

\section{References}

Akintonwa A, Busari AA, Awodele O, Olayemi SO. "The Hazard of NonIonizing Radiation of Telecommunication Mast in Urban Area of Lagos, Nigeria". African J Biomedical Res 2009; 12(1): 31-5.

Enrique AN, Segura J, Portolés M, GómezPerretta $\mathrm{C}$ et al., "The Microwave Syndrome: A Preliminary Study in Spain". Electromagnetic Biol Med 2003; 22 (2): 161-9.

Gerard VS. Updating Policy on Latest Risks for Students with Cell Phones in the School. Edu Digest 2006; 72(4): 43-6.

Horst E, Hagen KU, Lucas B, Vogel P, Voit H. "The Influence of Being Physically Near to a Cell Phone Transmission Mast on the Incidence of Cancer." Umwelt· Medizin. Gesellschaft 2004; 17. The poerwatch.uk website. [Online]

Hutter HP, Moshammer H, Waller P, Kundi M. "Subjective, Sleeping Problems, and 
Cognitive Performance in Subjects Living Near Mobile Phone Base Station". Occup Environ Med 2006; 63:307-13.

Hyland GJ. "Physics and Biology of Mobile Telephony." The Lancet 2000: 356: 1833-6.

Khan AR, Zaman N, Muzafar S. Health Hazards Linked to Using Mobile Cellular Phones. J Information Communication Technol 2008; 2(2): 101-8.

Michael M, Colin B, Mika K. The health hazards of mobile phones. Br Med J 2000; 320: 1288-9.

Oberfeld G, Enrique AN, Manuel P, Ceferino M, Gomez-Perretta C. "The Microwave Syndrome - Further Aspects of a Spanish Study." 2004. The tetrawatch website. [Online]

Obringer JS, and Coffey K. Cell Phones in American High Schools: A National Survey. J Technol Studies 2007; 33(1): 41-7.

Otitoloju AA, Obe IA, Adewale OA, Otubanjo OA, Osunkalu VO. "Preliminary Study on the Induction of Sperm Head Abnormalities in Mice, Musmusculus, Exposed to
Radiofrequency Radiations from Global System for Mobile Communication Base Stations". Bull Environ Contam Toxicol 2010; 84: 51-4.

Santini R, Santini P, Danze JM, LeRuz P, Seigne M. "Survey Study of People Living in the Vicinity of Cellular Phone Base Stations". Electromagnetic Biol Med 2003; 22 (1): 41-9.

Szentpali B. Human exposure to electromagnetic fields from mobile phones. In: Proceedings of the 4th International conference on telecommunications in modern satellite, cable and broadcasting services 1999; 1 : 222-31.

Viel JF, Clerc S, Barrera C, Rymzhanova R, Moissonnier M, Hours M, Cardis E. "Residential Exposure to Radiofrequency Fields, from Mobile Phone Base Stations, and Broadcast Transmitters: A Population-Based Survey with Personal Meter". Occup Environ Med 2009; 66: 550-6.

World Health Organization. Electromagnetic fields and public health: mobile phones. 2011; Fact sheet No.193.

Zirkel PA. Calling off Cell Phones. Phi Delta Kappan, 2008; 89(6): 464-6.

\section{How to cite this article:}

Ragini Saxena and Kumawat, D.M. 2018. Effects of Mobile Phone and Base Station Radiations on Living Being. Int.J.Curr.Microbiol.App.Sci. 7(06): 1086-1096. doi: https://doi.org/10.20546/ijcmas.2018.706.129 